\title{
RESEPSIETEORIE: KONKURRENT OF KOMPLEMENT VAN DIE TEKSIMMANENTE EKSEGESE?
}

P J BOTHA

\begin{abstract}
Reception theory: competitor or complement of text-immanent exegetical methodology?

Due to the underlying principles on which it was based and which suggest a critical view of positivism and its idea of applying an exegetical "method" to a text, it seems as if the reception theory could only be regarded as an alternative to text-immanent exegesis. This paper reflects on the possibility of incorporating the insights of the reception theory into a textimmanent model so as to form a comprehensive exegetical approach.
\end{abstract}

\section{Inleiding}

Eksegetiese benaderings het in die twintigste eeu plus-minus die spektrum van moontlike paradigmas in terme van die kommunikasiemode ${ }^{11}$ deurloop. Aan die begin van die eeu was/historieselondersoeke/die eksegetiese metode by uitstek, 'n benadering waarin op die verhouding tussen sender en teks gekonsentreer is, dit wil sê waarin veral navorsing gedoen is oor die ontstaan van Bybelse tekste. In hierdie genetieskousale verklaringswyse van tekste, ${ }^{2)}$ is daar groot klem gelê op die bedoeling van die "oorspronklike outeur"."3) In die tydperk daarna het strukturele ondersoeke die teks self beklemtoon en dit die voorwerp van ondersoek gemaak. Nie die geskiedenis van sy ontstaan nie, maar die teks self, soos dit voor die ondersoeker lê, is as voonwerp van ondersoek uitgesonder. Sedert die sestigerjare het die resepsieteorie egter 'n invloed op eksegese van Bybelse tekste begin uitoefen. Hierdeur is die laaste dimensie, naamlik die verhouding tussen teks en ontvanger, op die voorgrond geplaas. Volgens die resepsieteorie vorm die leser en die inset wat hy lewer, 'n integrale deel van die kommunikasieproses, en is hy inderdaad skeppend betrokke by die verstaansproses, selfs by die totstandkoming van die teks as kommunikasiemedium.

Die epistemologiese vertrekpunt van elkeen van hierdie benaderingswyses verskil van dié van die ander, of weerspreek dit in só 'n mate dat histories-kritiese eksegese, struktuur-gerigte benaderings en 'n 
resepsieteoretiese lees van die teks as alternatiewe metodes gesien word. In hierdie ondersoek word die vraag gevra of die verskillende metodes noodwendig as konkurrente gesien moet word, en of die resepsieteorie nie as komplement tot die teksimmanente eksegese gereken kan word nie. Om hierdie vraag te kan beantwoord, moet die vertrekpunt van elkeen van hierdie benaderings kortliks ondersoek word.

\section{Historiese ondersoeke en teksimmanente eksegese}

Tussen die histories-kritiese benadering en die teksimmanente (struktuur-analitiese) eksegese bestaan - ten minste - 'n oppervlakkige ooreenkoms: albei metodes hou verband met ontwikkelinge in die literatuurwetenskap ${ }^{4)}$ en albei het ontstaan as 'n uitvloeisel van bepaalde taalkundige insigte. So was dit die insig dat Hebreeus nie'n Goddelike taal of lingua sacra is nie, maar 'n Semitiese dialek naas andere, wat die weg gebaan het vir 'n kritiese beskouing van die ontstaan van die Pentateug en sodoende die histories-kritiese eksegese in die lewe geroep het.5) Aan die ander kant het De Saussure se insig dat taal 'n stelsel van interafhanklike terme is waarin die waarde van elke term deur die gelyktydige teenwoordigheid van die ander terme bepaal word, weer gelei tot 'n strukturele benadering van taal waarin sinkroniese linguïstiek sowel in belang as in volgorde van toepassing bo diakronie prioriteit begin geniet het.6)

Dit was egter juis laasgenoemde onderskeid tussen sinkronie en diakronie wat vyandskap gebring het tussen 'n historiese en 'n teksimmanente benadering van Ou-Testamentiese tekste. Nie die geskiedenis van ' $n$ woord of teks nie, maar die onderlinge relasie van die dele in die teks op 'n gegewe tydstip word as deurslaggewend beskou vir die betekenis daarvan. Teksimmanente gegewens moet dus ondersoek en oorweeg word voordat teksemanente data aan die orde kom; die struktuur moet vasgestel word voordat die wordingsgeskiedenis nagegaan word. In teenstelling met die kritiese benadering, het 'n veranderde epistemologie die sogenaamde post-kritiese fase ingelui waarin 'n nuwe vorm van kritiese wetenskap onderskei kon word.7)

'n Onlangse manifestasie van hierdie teenstelling tussen die finale vorm van 'n teks en sy wordingsgeskiedenis, word gevind in die sogenaamde kanonieke benadering waarin gestreef word om reg te laat geskied aan "die integriteit van die teks self sonder diakronistiese rekonstruksie". $\left.{ }^{8}\right)$ Hoewel die wordingsgeskiedenis van die teks hierin nie ontken word nie, word die eksegetiese waarde van die navorsing daarvan van weinig belang geag vir die verstaan en gesag van die finale vorm.

Die histories-kritiese eksegese en die teksimmanente benadering hoef egter nie op grond van De Saussure se onderskeid tussen sinkronie 
en diakronie wedersyds uitsluitend geag te word nie. Die insig dat taal gestruktureerd is, beteken bloot dat die twee benaderings nie planloos vermeng moet word nie. 'n Struktuuranalitiese benadering sluit nie historiese gesigspunte uit nie, maar ken slegs aan 'n sinkroniese en teksimmanente benadering metodologiese prioriteit toe. Dit is nog steeds van nut om meer te verstaan oor die ontstaan van die teks waarmee gewerk word, mits sodanige gegewens binne 'n sinkroniese raamwerk geïntegreer kan word. $\mathrm{Na}$ 'n aanvanklik reaksionêre fase waarin struktuur ter wille van struktuur moontlik verabsoluteer is, het die pendulum begin terugswaai en is aan buite-tekstuele aspekte algaande meer aandag gegee, juis op grond van die teks self.9)

\section{Die resepsieteorie en teksimmanente eksegess}

'n Verdere verbintenis tussen historiese eksegese en die teksimmanente benadering is daarin geleë dat albei dikwels verbind word met ' $n$ positivistiese strewe na objektiwiteit. Kraus" ${ }^{10)}$ skryf byvoorbeeld: "Ein idealistisches Wahrheitsstreben bestimmt den historisch-kritischen Forscher." Deist"1) praat van die "onverteerde positivisme" wat in De Saussure se struktuurbegrip bly steek het en dikwels onverpoos voortleef in die diskoersanalise. ${ }^{12)}$ Omdat teksoutonomie in die struktuur-georiënteerde benaderings voorrang geniet, het die fenomenologiese objektiwiteitsideaal wat daaraan ten grondslag lề ${ }^{13)}$ 'n onmiskenbare rol gespeel.

Die resepsieteorie daarteenoor, word egter gekenmerk deur 'n afkeer van enige empiriese epistemologie wat kennis beskou as 'n reeks universeel-geldige stellings wat uit die persepsie van feite geabstraheer is. Subjektiwiteit en vooroordeel het sedert die Aufklärung 'n negatiewe konnotasie verkry vanweë die metodologie en empiriese epistemologie van die natuurwetenskappe. In navolging van die filosofie van Heidegger het Gademer egter juis Vorurteil tot voorwaarde vir die moontlikheid van verstaan verhef, ${ }^{14)}$ en hierdie gedagte, wat die grondslag vorm vir sy begrip van Wirkungsgeschichte, het op sy beurt 'n belangrike invloed op die resepsieteoretici uitgeoefen. ${ }^{15}$ ) Subjektiwiteit is nie meer 'n struikelblok in die eksegese nie, dit is die bestaansvoonwaarde vir verstaan.

Dit wil dus voorkom of die uitgangspunt van die resepsieteorie met die meer tradisionele eksegese in botsing kom. Daar word nie in die resepsieteorie na 'n objektiewe of intersubjektiewe betekenis van die teks gevra nie. In die resepsieteorie word die konsepsie van die teks as objektiewe gegewe met 'n enkele, vasgestelde betekenis boonop verruil vir'n verskeidenheid modelle waarin die teks 'n nooit-voltooide ontvouing van sy eie Wirkungsgeschichte is, terwyl die betekenis daarvan saamgestel word deur die interaksie tussen die teks en die leser. ${ }^{18)}$ Die leser, wat nou ' $n$ belangrike plek inneem in die eksegetiese proses, is immers ' $n$ teks- 
emanente gegewe en die vryheid van interpretasie word nou bo die objektiewe soeke na betekenis verhef. Dit wil voorkom of die Gereformeerde beginsel van sola scriptura verruil word vir een van solus lector. Om die moontlike versoenbaarheid van teksimmanente eksegese en die resepsieteorie te kan oorweeg, sal meer gesê moet word oor die teoretiese onderbou van laasgenoemde benadering.

\section{Die ontwikkeling van die resepsieteorie ${ }^{17)}$}

Die naam "resepsieteorie" het sy ontstaan te danke aan die Duitse term Rezeption en weerspieél die literêre benadering wat gedurende die afgelope anderhalf dekade in Duitsland, en by name by die Universiteit van Konstanz, ontwikkel het. Mettertyd het 'n parallelle maar onverwante en minder eenvormige beweging in Noord-Amerika ontstaan, die sogenaamde "reader response criticism". Die naam "reader response criticism" is egter ex post facto op 'n aantal skrywers toegepas en die enigste werklike verbintenis tussen die Duitse en Amerikaanse benadering bestaan daarin dat albei op die teks:léser-pool fokus en dat Wolfgang Iser, ' $n$ belangrike eksponent van die resepsietoerie, ook tot die geledere van die "reader response criticism" gereken word. ${ }^{18)}$

Die aanleidende faktore vir die ontwikkeling van hierdie nuwe benadering deur geleerdes aan die Universiteit van Konstanz moet gesoek word in die politieke en literêre konflik in na-oorlogse Duitsland. Belangrike eksponente van die resepsieteorie, by name Hans Robert Jauss, Wolfgang Iser en Siegfried Schmidt, het hulle in die 1960's daartoe verbind om die studie van literatuur in Wes-Duitsland institusioneel en metodologies te herstruktureer as 'n reaksie teen die bastion van nasionaal-sosialistiese metodologie en die invoer van "neutrale" onderwys in die na-oorlogse jare. ${ }^{19)}$ Hulle poging het ondersteuning gekry, en is beïnvloed vanuit 'n verskeidenheid oorde soos onder meer die Russiese formalisme, die Praagse strukturalisme en die literêre sosiologie, asook van veral twee individue, Roman Ingarden en Hans-Georg Gadamer.

Uit die Russiese formalisme was dit veral die begrip van "vervreemding" wat 'n bepalende invloed uitgeoefen het op die resepsieteorie. Die doel van kuns is om ontdekking van die onderwerp te bewerk in die sin van "sien" eerder as "herken". Ostranenie of "vervreemding" is die tegniek wat die gaping tussen teks en leser oorbrug. ${ }^{20}$ ) Dié tegniek is die manier waarop die leser se persepsie van 'n objek gedeoutomatiseer word, sodat hy nie net herken nie, maar linguïstiese en sosiale konvensies in 'n nuwe lig sien.. ${ }^{21)}$

Roman Ingarden se bydrae het gekom deur sy studie van die leesproses en die kognisie van literêre werke. Volgens hom is die literêre werk 
opgebou uit lae en dimensies wat 'n raamwerk of "geskematiseerde struktuur" vorm, sodat die leser self die onbepaalde gedeeltes kan invul of konkretiseer. ${ }^{22)}$ Dit is duidelik dat die envaring, kreatiwiteit, insig en perspektief van die leser ' $n$ rol speel in sy konkretisering van die literêre werk. Volgens Ingarden se model bestaan daar dan 'n skerp onderskeid tussen die stabiele struktuur van 'n literêre werk en die leser se eie hantering van hierdie struktuur. ${ }^{23)}$ Die Praagse strukturaliste, by name Mukarovsky en Vodicka, het 'n bydrae gelewer deur op die sosiologiese dimensie van kuns te wys. Die lees van tekste is volgens hulle insig nie 'n gebeure waarby die individu as sodanig betrokke is nie. Volgens Mukarovsky is kuns 'n dinamiese tekensisteem waarin sowel die kunswerk as die interpreteerder deur 'n bepaalde sosiologiese struktuur "deurdring" is. ${ }^{24)}$

Die agtergrond en besondere bydrae van bogenoemde groepe vertoon feitlik deurgaans 'n strukturalistiese inslag en 'n soeke na metodologie. Die werk van Hans-Georg Gadamer daarenteen, skyn of dit teen die grein van resepsieteoretici moet indruis, aangesien hy ten sterkste gekant is teen enige metode wat 'n subjek op'n objek kan toepas om 'n gewaande waarheid te abstraheer. ${ }^{25)}$ Hy stel hermeneutiek as korrektief en metakritiese oriëntasie voor om die beperkings van metodologie te corkom. ${ }^{26}$ ) Uit hoofde van sy filosofiese en ontologiese vertrekpunt verhef hy historisiteit - wat deur die wetenskap as struikelblok in die strewe na objektiewe kennis gesien is - tot die prinsipe van verstaan. Dit is die mens se in-die-wêreld-wees met al sy vooroordeel en voorveronderstellings, wat verstaan moontlik maak: Vorurteil is 'n voorwaarde vir verstaan omdat dit tot die historiese realiteit self behoort. ${ }^{27)}$ Die proses van verstaan is volgens hom ' $n$ versmelting (Horizontverschmelzung) tussen die leser se eie agtergrond en die horison van die teks. Dit is veral sy begrip van Erwartungshorizont wat toepassing gevind het binne die resepsieteorie, ten spyte van die feit dat Gadamer die toepassing daarvan in 'n nuwe metodologie nie sou kondoneer nie. ${ }^{28)}$

Die laaste belangrike invloed het gekom van die literêre sosiologie. Die aksent wat hierdie beweging geplaas het, is dat die studie van resepsie van literatuur ook 'n bydrae kan en moet lewer tot sosiale analise van faktore soos instellings wat 'n bepaalde smaak bevorder, organisasies wat denkrigtings beïnvloed en selfs die funksie van boekwinkels en uitgewers as deel van 'n literêre geskiedenis. ${ }^{29)}$ Die effek of invloed wat 'n literêre werk het, behoort tot die wese daarvan; die werk word bepaal deur hoe dit geresepteer word. ${ }^{30}$ )

'n Analise van hierdie oorsig oor die vormende invloede van die resepsieteorie toon dat hulle in twee kategorieë verdeel kan word. Daar is dié denkrigtings wat die inherente struktuur en tegniek van die teks as 
gegewe vertrekpunt neem, maar ook vra na die effek of pragmatiek van die teks (die Russiese formalisme, Praagse strukturaliste en Roman Ingarden). Daarteenoor is daar dié rigtings wat primêr in die teksemanente faktore geïnteresseerd is (Gadamer en die literêre sosiologie).

Die twee belangrikste eksponente van die resepsieteorie is sekerlik Jauss en Iser. Hoewel albei aan die Universiteit van Konstanz verbonde is, het hulle verskillende aksente geplaas. Jauss is dosent in Romaanse tale, geïnteresseerd in die bydrae van die resepsieteorie tot die studie van literêre geskiedenis en het veral beïnvloeding van Gadamer ondergaan; Iser bestudeer Engelse literatuur en is meer geïnteresseerd in die effek van individuele tekste op die leser, en het daarom meer gesteun op die fenomenologiese werk van Ingarden. ${ }^{31)}$ Omdat Jauss hom besig hou met breë sosiologiese en historiese kwessies - die makrokosmos van literatuur - en tekste slegs illustratief gebruik, sal vervolgens slegs die bydrae van Iser ${ }^{32}$ bespreek word. Iser se metode het groter toepassingswaarde op die Ou Testament.

\section{Die benadering van Wolfgang Iser}

Die vraag waarmee Iser hom besig gehou het, was hoe en onder watter omstandighede ' $n$ teks betekenis het vir ' $n$ leser. ${ }^{33)}$ Betekenis is volgens hom nie in die teks opgesluit nie, maar is die gevolg van interaksie tussen die teks en die leser, 'n effek wat ervaar word, nie 'n objek wat gedefinieer word nie. ${ }^{34}$ Sodoende verskuif die fokus van die teks as objek na die handeling van lees as 'n proses. ${ }^{35)}$

Soos Ingarden beskou Iser die teks as 'n raamwerk van geskematiseerde aspekte wat deur die leser geaktualiseer of gekonkretiseer moet word. ${ }^{36)}$ Iser het die konsep van "geïmpliseerde leser" as teenhanger vir die begrip "geïmpliseerde outeur", wat deur Booth geskep is, geïnsieer. ${ }^{37)}$ Met "geïmpliseerde leser" bedoel hy sowel die voorafstrukturering van die potensiële betekenis van die teks, as die leser se aktualisering van dié potensiaal deur die leesproses. ${ }^{38)}$ Die "geïmpliseerde leser" is dus 'n middel waardeur die werklike leser betrek word, deurdat dit hom 'n rol aanbied wat hy kan speel of 'n houding wat hy kan inneem. ${ }^{39)}$ Iser is gekritiseer oor die dubbele funksionaliteit van hierdie konsep waardeur hy tussen teks en leser kan beweeg sonder om ooit die samestelling of die funksie van die twee helftes van die vennootskap presies te definieer. ${ }^{40)}$

Teks en leser ontmoet mekaar dus volgens Iser om kommunikasie te bewerk. Die konvensies wat nodig is om die ontmoetingsituasie tot stand te bring, noem hy die repertoire. Dit bestaan uit die bekende 
gegewens in die teks, soos byvoorbeeld verwysings na vroeëre werke, sosiale of historiese norme of selfs die kultuur-agtergrond van die teks. ${ }^{411}$

'n Verdere tweesnydende konsep van Iser is dié van "strategiee"” in die teks. Hulle omvat sowel die immanente struktuur van die teks, dit wil sê die vorm waarin die repertoire aangebied word, as die verstaanshandelinge wat daardeur in die leser geaktiveer word. ${ }^{42}$ ) Strategieë verwys volgens hom nie na tradisionele narratiewe en retoriese tegnieke nie, maar na die strukture wat die onderbou vorm van sodanige tegnieke en hulle toelaat om 'n effek te hê op die leser. ${ }^{43)}$ Hulle funksie is ten diepste om die bekende te vervreem ("defamiliarise") en daartoe dien die beheerstrukture van voorgrond en agtergrond, en tema en horison onderskeidelik.44) Die voorgrond-agtergrond-onderskeid verwys na die relasie wat sommige elemente van die teks laat uitstaan en ander met die konteks laat saamsmelt, sodat die persepsies van die leser beheer word en betekenis sodoende geskep word.45) Die terme "tema" en "horison" het weer met die seleksie van 'n verskeidenheid perspektiewe in 'n teks te make: daar is die perspektief van die verteller, van die karakters, van die intrige, en die perspektief wat vir die leser geselekteer is. ${ }^{46)}$ Die leser word deur vorige leeservaring en deur hierdie perspektiewe gekondisioneer sodat die spanning tussen tema en horison 'n meganisme skep wat persepsie beheer. ${ }^{47)}$

'n Verdere belangrike konsep vir Iser is dié van die verskuiwende gesigspunt. In die proses van betekenis-skepping probeer die leser om verbande te lê tussen die verskillende tekens en skemas van die teks. Wanneer hy iets teenkom wat met sy geheelbeeld (Gestalt) in konflik verkeer, maak hy die nodige aanpassings sodat die sinvolheid van sy konsepsie herstel kan word. Op hierdie manier ontstaan 'n dialektiek tussen beeldskepping en beeldaanpassing en tussen betrokkenheid en waarneming. ${ }^{48)}$

Laastens kan gewys word op die belang van gapings in die teks. Sogenaamde gapings is ' $n$ tegniek van die teks om beheer uit te oefen oor die dialoog tussen teks en leser. Omdat die leser nie vrae kan stel aan die teks nie, moet hy self sekere inligting voorsien. Gapings kan oop plekke, leë plekke of ontkennings wees. 'n Oop plek verwys na onderbrekings in die verhaal, terwyl leë plekke die nie-tematiese segmente in die verwysingsveld van die verskuiwende gesigspunt is. ${ }^{49)}$ Oop plekke of onderbrekings in die verhaal lok die leser uit om onderskeie segmente self te verbind. Sodanige verbintenis konstitueer 'n gesigsveld vir die verskuiwende gesigspunt, aangesien een segment die ander in belang sal oorheers. Die oplossing van hierdie spanning is op sy beurt ' $n$ oorbrugging van 'n leë plek, aangesien die leser 'n abstrakte raamwerk moet voltooi ten 
einde die segmente te orden. ${ }^{50)}$ Sodra struktuur daargestel is, ontstaan leë plekke op die vlak van tema en horison.51) Oop plekke en leë plekke beplan sodoende op sintagmatiese vlak die roete vir 'n lesing van die teks deur die leser se deelname te organiseer en hom te verplig om die struktuur te voltooi. ${ }^{52)}$ Leë plekke kan ook in die paradigmatiese dimensie ontstaan, naamlik deurdat die aanvaarde norme van die leser bevraagteken word. Sodoende ontstaan 'n ontkenning of negasie. Deurdat leë plekke in die teks self ingevul word, verkry die leser 'n perspektief waaruit vroeëraanvaarde norme ongeldig blyk te wees. ${ }^{53)}$

Botha ${ }^{54)}$ gee die volgende skematiese voorstelling van hoe die interaksie tussen teks en leser volgens Iser verloop:

Teks > Oop plekke ("blanks") in die teks > word ingevul deur die leser > verwysingsveld ontstaan $>$ word ingevul deur die tema-en-horison-struktuur > Leë plekke ("vacancies") ontstaan > dit word ingevul deur die leser se horison $>$ onderlinge transformasies vind plaas $>$ dit lei uiteindelik tot die vorming van die estetiese objek.

\section{Die resepsieteorie as komplement van Ou-Testamentiese eksegese}

Die vraag of die resepsieteorie se insigte te rym is met 'n tradisionele eksegetiese benadering, moet sentreer om die kwessie van die outonomiteit van die teks.

Die resepsieteorie gaan hand aan hand met 'n reaksie teen die strewe na objektiwiteit. ${ }^{55)}$ Enersyds het die afwysing van objektiwiteit in die geesteswetenskappe gedurende die sestigerjare tot 'n vlaag van skeptisisme en relativisme gelei. ${ }^{56)}$ Hierdie skeptisisme het binne die breë resepsieteorietiese beweging enersyds tot die sogenaamde "dekonstruksie" of "post-strukturalisme" gelei. Andersyds het resepsieteoretici daarop gewys dat daar 'n onderskeid bestaan tussen die intersubjektiefverifieerbare instruksies vir betekenisskepping in die teks, en die subjektiewe oordeel oor daardie instruksies wat by verskillende lesers in die proses van betekenisskepping ontstaan. ${ }^{57)}$ Hoewel die verstaanshandeling dus gerig word deur die strukture van die teks, kan die teks nie volkome beheer uitoefen oor die leser nie. Dit is inderdaad die element van onbepaaldheid in die teks wat die leser uitlok tot 'n dialoog en die skepping van betekenis. ${ }^{58)}$

Om totale subjektiwisme te vermy, word daar dus vasgehou aan die struktuur van die teks. Gevolglik ontstaan onduidelikheid oor die verhouding waarin die teks en die leser onderskeidelik bydra tot betekenisskepping. Die beperkinge wat die teks op 'n verkeerde verstaan plaas en die vryheid van die leser is 'n paradoks wat om groter helderheid vra. ${ }^{59}$ ) Indien 
die outonomiteit van die teks gehandhaaf word, het die resepsieteorie volgens $\mathrm{Holub}^{60)}$ geen bydrae gelewer nie; indien die outonomiteit van die leser ten koste van die teks gehandhaaf word, verval eksegese in 'n soort vrye spel van betekenistoekenning, soos die ludisme wat in die dekonstruksie-beweging manifesteer.61) Die oplossing wat hier voorgestel word, is dat sowel teks as leser as outonoom in eie reg gesien sal word, en dat betekenis as die resultaat van kontak tussen dié twee outonome elemente gedefinieer sal word. 'n Gebalanseerde toepassing van teksoutonomie in Bybelse hermeneutiek kan bepaalde hermeneutiese dwalinge voorkom; ${ }^{62)}$ so kan 'n gebalanseerde toepassing van leseroutonomie die positivistiese trek in strukturalisme met ' $n$ realistiese epistemologie vervang.

Sommige eksponente van die resepsieteorie het die paradoks probeer oplos deur te praat van die teks as 'n oorbepaalde struktuur. Dié term, wat deur Freud geskep is in sy beskrywing van gedrag, impliseer dat ' $n$ veelheid van determinante, waarvan sommige teenstrydig kan wees, betrokke is by die ontstaan van 'n teks en dat die teks dus meer as een betekenis het. ${ }^{63)}$ In die lig van die feit dat Jauss en Iser se grondliggende beswaar teen die tradisionele wyse van interpretasie die aanvaarding van 'n enkelvoudige beteken is was, ${ }^{64)}$ is die mees ingrypende bydrae van die resepsieteorie, hulle insig dat een en dieselfde teks op verskillende geldige maniere gelees en verstaan kan word, en dat niemand die alleenreg tot interpretasie het nie. ${ }^{65)}$ Deist het dus rede gehad om te waarsku ${ }^{66}$ ) dat die struktuuranalise van 'n teks nie die "betekenis" van 'n teks na vore bring nie: "Struktuuranalise lewer 'n deskripsie en kan nie 'n heuristiese model wees nie. 'n Struktuuranalise kan hoogstens 'n argument wees waarom ek die teks só en nie só nie interpreteer."

Met die propagering van De Saussure se insig dat taal gestruktureer is, is die logosentrisme van vroeëre benaderings afgewys. Dit is egter 'n geldige vraag om te wil weet of logosentrisme nie in sommige gevalle bloot vir ' $n$ tekssentrisme verruil is nie. Woorde het nie betekenis nie, maar betekenismoontlikhede wat binne 'n bepaalde konteks realiseer. Die resepsieteorie sou bywoeg dat tekste ooknie betekenis het nie, maar slegs betekenismoontlikhede wat deur interaksie van teks en leser kan realiseer. In 'n nuwe komprehensiewe model moet nie die epistemiese status van die teks nie, maar die epistemiese status van betekenis gewysig word. Dat betekenis deur interaksie van teks en leser ontstaan, kan dus binne 'n teksimmanente model geïntegreer word. Solank teksimmanensie nie teksimmanisme word nie, en mits die teks nie bloot as ' $n$ funksie van die leesproses gedefinieer word nie, kan struktuur-georiënteerde eksegese deur die resepsieteorie aangevul word.

Die voorvereiste is egter dat die volgorde teksimmanent-teks- 
emanent gehandhaaf word, net soos die volgorde sinkronie-diakronie teenoor die histories-kritiese eksegese as toelatingsvereiste tot die teksimmanente model gestel is. Verder moet beklemtoon word dat 'n struktuuranalise die voorvereiste vorm vir 'n lesersgeoriënteerde benadering. As 'n strukturele raamwerk die gereedskap is waarmee die resepsieteorie werk, moet sodanige gereedskap op intersubjektiewe wyse geïdentifiseer kan word. 'n Struktuuranalise moet dus nooit teenoor ' $n$ resepsieteoretiese ondersoek gestel word nie. Sodanige implementering van die resepsieteorie sal nie alleen 'n noodsaaklike korrektief bring op die positivistiese wanopvatting dat struktuur betekenis is nie, ${ }^{67)}$ maar ook die oog open vir die struktuurmerkers in die teks wat op die leesproses gerig is. Sodoende word die resepsieteorie die heuristiese model wat die struktuuranalise in die soektog na betekenis aanvul, 'n maat wat by hom pas.

Waar daar voortaan nie na "die betekenis" of "die korrekte verstaan" van 'n teks verwys kan word nie, is dit nodig om van 'n meer of minder geslaagde voltrekking van die kommunikasieproses te praat. 'n Naïewe lees van die Ou Testament deur 'n gemiddelde lidmaat lewer dus 'n geldige verstaan van die bepaalde teks, hoewel daar nie sprake is van 'n optimale voltrekking van die kommunikasieproses nie. Waar die leser egter op hoogte is van die literêre konvensies en 'n bepaalde metode aanwend om 'n geldige struktuur in die gedeelte te identifiseer, is die kans dat die kommunikasie tussen sender en ontvanger meer geslaagd sal wees, veel groter.

Die outonomiteit van die teks en die outonomiteit van die leser word dus nie as wedersyds uitsluitend beskou nie. Die teks is stabiel en gestruktureer; die leser kan met die teks omgaan soos wat hy wil, maar die effek (betekenis) van die teks is 'n produk van die verbinten is van die twee. 'n Sin soos "die kind rol die bal" is dus outonoom daarin dat dit 'n gestruktureerde taaluiting is en bly bestaan - of dit gelees word of nie. Tog het die leser self ' $n$ bydrae te lewer in die leesproses, omdat hy die geslag, ras, ouderdom, gelaatstrekke, en so meer, van die kind as oop ruimtes ervaar wat hy skeppend moet "invul". Wat die teks vir hom beteken, word bepaal deur sy agtergrond, geestesgesteldheid, opvoedingspeil, en so meer selfs deurvorige ervaring van dieselfde of soortgelyke tekste. Die werklike betekenis vir 'n bepaalde leser word egter gereguleer en beperk deur die struktuur van die teks: Die kind kan nie pasgebore wees nie, die bal kan nie te groot en swaar wees nie, ensovoorts.

Die optimale verstaan van 'n teks is nie dié betekenis wat die meeste werklike lesers produseer nie, maar dié betekenis wat ontstaan wanneer alle gegewens in die teks in ag geneem word, insluitende dié wat 'n profiel teken van die leser wat die outeur primêr in gedagte gehad het. Indien die 
teks bedoel is vir wit Afrikaanssprekende lesers en boonop gesê word dat die toneel in 'n huis in 'n bekende woonbuurt vir wittes afspeel, sal 'n denkbeeld oor ' $n$ anderskleurige kind wat 'n bal rol, uiteraard minder geslaagd wees. Dit is daarom ewe belangrik dat die leser bewus sal wees - en bereid sal wees om rekenskap te gee - van sy eie verstaanshorison. Op hierdie wyse kan 'n versmelting van die leser se verstaanshorison en die horison van die leser in die teks bewerkstellig word, 'n proses wat op sy beurt tot ' $n$ meer geslaagde kommunikasie tussen outeur en werklike leser sal lei.

Wat hier bepleit word is derhalwe 'n realistiese epistemologie ${ }^{68)}$ waar in aanvaar word dat stellings oor die betekenis van 'n teks altyd beter of swakker benaderings van die werklikheid sal wees, en dat daar op rasionele gronde deur middel van vervalsing eerder as verifikasie beslis kan word tussen meer en minder geslaagde voltrekkings van die kommunikasieproses. Die alternatief tot objektivisme is sekerlik nie algehele relativisme of skeptisisme nie. ${ }^{69)}$ Die epistemiese ideaal moet wees om bevindinge te genereer wat so na as moontlik aan algehele sekerheid kom.

Indien aanvaar word dat daar altyd interaktiewe balans tussen teks en leser sal wees, dit wil sê, dat die mate van kommunikasie tussen die teks en elke leser direk eweredig is aan die hoeveelheid toerusting (inligting, ervaring) waarmee die leser na die teks kom, sal die mees suksesvolle voltrekking van die kommunikasieproses sekerlik daar geskied waar die leser so goed as moontlik ingelig is. Die strewe na objektiwiteit het nog altyd gewaarsku dat eksegese nie inlegkunde moet wees nie. Waar niks ingelê word nie, kan daar egter ook geen uitleg wees nie. Daarom moet die strewe veeleer wees na 'n kontrole oor die proses van lees, en hiertoe bied die immanente struktuur van die teks 'n bepalende riglyn.

\section{Winspunte van die resepsieteorie}

'n Eerste winspunt van die resepsieteorie, wat hierbo reeds bespreek is, is die insig dat ' $n$ teks slegs betekenismoontlikhede het, en dat hierdie moontlikhede deur verskillende lesers op verskillende maniere gerealiseer kan word. Daarbenewens het dié beweging ander insigte en apparaat gekonseptualiseer wat 'n belangrike bydrae kan lewer tot die eksegetiese proses wat as omvattende benadering beoefen word.

Die klem wat die resepsieteorie op die effek of Wirkung van resepsie gelê het, verklein die moontlikheid om in strukturalisme te verval waarin die maak van 'n struktuuranalise die einddoel van eksegese is. Dit help dat altyd gevra word na die funksie van die struktuur van die teks en van elemente in die teks. Selfs faktore soos subjekwisseling en segmentering 
in die teks, wat deur middel van die struktuuranalise geidentifiseer word, moet resepsieteoreties verdiskonteer word. 'n Duidelike verdeling tussen twee strofes of stiges in 'n Ou-Testamentiese psalm beteken byvoorbeeld 'n gaping in die teks wat deur die leser oorbrug moet word. Die vraag na binding tussen strukturele eenhede verteenwoordig sodoende reeds die corbrugging van 'n gaping. Die gebruik van 'n tabulering van lekseme wat binne 'n bepaalde gedeelte herhaal word, behels die identifikasie van temas wat as padtekens in die leesproses dien. 'n Analise van die persoonsvorme van 'n gedeelte sê reeds veel oor die implisiete outeur en implisiete leser, ensovoorts.

Daarbenewens het die resepsieteorie groter klem geplaas op die historiese gesitueerdheid van ' $n$ teks en sy lesers. Jauss ${ }^{70}$ ) is bywoorbeeld uitgesproke daaroor dat hy die gaping tussen literatuur en geskiedenis, tussen historiese en estetiese benaderings, wil oorbrug. Die geskiedenis van die resepsie van tekste het daardeur 'n belangrike hupstoot gekry. Kennis van die verstaan van 'n teks in verskillende diakronies opeenvolgende lesersituasies is van groot belang vir die huidige leser, omdat vorige verklarings van tekste 'n invloed uitoefen op die toerusting waarmee hyself lees. Die leser se verstaan van homself en van sy eie envaring ten opsigte van ' $n$ teks is van groot belang in die realisering van geslaagde kommunikasie.

Dit alles wil nie impliseer dat die resepsieteorie as nuwe paradigma binne die literatuurwetenskap 'n seepgladde inlywing binne 'n omvattende eksegetiese benadering gaan vind nie. Die resepsieteorie was in sy ontstaan primêr met fiksie-tekste gemoeid ${ }^{71)}$ en sekere aanpassings sal dus noodsaaklik wees wanneer met Bybelse tekste - waarin ander konvensies geld - gewerk word. Die Ou Testament bevat hoofsaaklik ideologiese tekste wat in wese oorredend van aard is. ${ }^{72)}$ Dit verhoog die bruikbaarheid van die resepsieteorie, maar stel terselfdertyd hoe eise aan die toepassing van die model. Die veronderstelling dat die leser sekere konvensies sal ken om die boodskap te kan dekodeer is van groter belang wanneer met ' $n$ antieke taal in 'n vreemde kultuur gewerk moet word. Daarbenewens kan, vanweè die komplekse ontstaansgeskiedenis van veral die Ou-Testamentiese boeke, moeilik van 'n implisiete outeur gepraat word - tensy die woorde na die auctor primarius verwys.

\section{Slot}

'n Prominente en geëerde Ou-Testamentikus het onlangs gesê dat daar geen ander eksegetiese metode is nie as net "lees, lees, en nogmaals lees van die teks". Dit is 'n stelling wat onderskryt kan word, mits die leser iets verstaan van die geskiedenis en struktuur van die teks, van die leesproses 
en van homself as leser, en mits hy al hierdie gegewens binne die parameters van "sinkronie voor diakronie" en "teksimmanent voor teksemanent" kan integreer. Soos die onvolledigheid van die histories-kritiese eksegese aanleiding gegee het tot die ontstaan van hermeneutiese modelle wat die kloof tussen die waarheidsappèl van die Bybel en die huidige konkrete situasie moet oorbrug, ${ }^{73)}$ so toon die resepsieteorie dat struktuurgerigte benaderings mank gaan aan dieselfde gebrek. Indien die samehang tussen die verstaan en toepassing van Bybelse tekste eerbiedig moet word, ${ }^{74}$ ) kan die rol van die leser nie langer in eksegetiese modelle geïgnoreer word nie. Die resepsieteorie is egter eweneens nie die afdoende antwoord nie. Tussen tese en antitese het dit tyd geword vir 'n sintese, 'n omvattende eksegetiese benadering waarin elke aspek sy regmatige plek opneem.

\section{NOTAS}

1. Vergelyk B C Lategan, "Inleidende opmerkings oor resepsieteorie en die uitleg van Bybelse materiaal", NGTT vol. 28 (1987), 112.

2. Vergelyk A G van Aarde, "Skrifgebruik: hermeneutiese riglyne", HTS vol 41 (1985), 549.

3. Vergelyk WS Vorster, "Op weg na 'n post-kritiese Nuwe-Testamentiese wetenskap", HTS vol 43 (1987), 381.

4. Vergelyk J Botha, "'n Verkenning van die moontlikhede van 'n resepsieteoretiese benadering tot die lees van Romeine 7:7-25, HTS vol 42 (1986), 283.

5. H-J Kraus, Geschichte der historisch-kritischen Erforschung des Alten Testaments, Neukirchen-Vluyn $21969,80-113$.

6. A C Thiselton, "Semantics and New Testament interpretation", in: I H Marshall (ed), New Testament interpretation, essays in principles and methods, 1977, 80-85.

7. Vorster, a $w, 375$.

8. B S Childs, Introduction to the Old Testament as scripture, London 1979, 74.

9. HJ B Combrinck, "Die pendulum swaai terug - enkeleopmerkings oor metodes van Skrifinterpretasie", Skrif en Kerk vol 4 (1983), 9.

10. Kraus, a w, 370.

11. F E Deist, "Ope vrae aan die diskoersanalise", NGTT 19 (1978), 261.

12. Vergelyk ook F E Deist, " 'Gekontroleerde 'eksegese en/of 'kreatiewe' uitleg", HTS 44 (1988), 43.

13. Van Aarde, a w, 550.

14. H-G Gadamer, Wahrheit und Methode. Grundzüge einer philosophischen Hermeneutik, Tübingen $41975,261$.

15. R C Holub, Reception theory, a critical introduction, London 1984, 44.

16. Holub, a w 148.

17. In die samestelling van die volgende oorsig is met vrug gebruik gemaak van die uitstekende corsig in Holub, a w, waarin uitvoerige bibliografiese gegewens gevind kan word.

18. Holub, a w, xii en xiii.

19. Ibid, 8, 9 .

20. J Streidter (ed), Texte der russischen Formalisten, Bd. 1:| Texte zur allgemeinen 
Literaturtheorie und zur Theorie der Prosa, München 1969, 14-15.

21. Holub, a w, 17-19.

22. RIngarden, The cognition of the literary work of art (trans! byRACrowley \& KR Olsen), Evanston 1973 [1937], 55-65.

23. Holub, a w, 27.

24. J Mukarovsky, Aesthetic function, norm and value as social facts (transl by M A Suino), Ann Arbor 1970 [1936], 83.

25. Vergelyk Gadamer, a $w, 5$.

26. Ibid, xxix.

27. Ibid, 261.

28. Holub, a w, 44.

29. Ibid, 50.

30. Vergelyk Botha, a $w, 287$.

31. Holub, a $w, 83$.

32. Benewens die corsig in Holub, a w, 53-81, kan Botha, a w, 288-290 ook geraadpleeg word. Botha a w,299-309 pas Jauss se begrip van "horisonverandering" in 'n resepsieteoretiese ondersoek van Romeine 7 toe.

33. Holub, a w, 83.

34. W Iser, The act of reading. A theory of aesthetic response (first published in German in 1976), London 1978, 9-10.

35. Botha, a $w, 291$.

36. Iser, a w, 1978, 21.

37. Holub, a $w, 84$.

38. W Iser, Der implizieten Leser; Kommunikationsformen des Romans von Bunyan bis Beckett, München 8-9.

39. Botha, a $w, 292$.

40. Holub, a $w, 85$.

41. Iser, a w, 1978, 69.

42. Ibid, 86.

43. Ibid, 87.

44. Ibid, 87-99.

45. Ibid, 95, vergelyk Holub, a $w, 88$.

46. Holub, a $w, 89$.

47. Iser, a $w, 1978,98-101$.

48. Ibid, 108-121.

49. Ibid, 198.

50. Ibid, 180-212.

51. Ibid, 198.

52. Holub, a $w, 94$.

53. Iser, a $w, 1978,212-225$.

54. Botha, a $w, 295$.

55. Vergelyk bywoorbeeld $\mathrm{H}$ R Jauss, Toward an aesthetic of reception (transl from the German by T Bathi), Minneapolis 1982, 20.

56. J Mouton, "Waarheid, metodologie en die voorcordeel jeens vooroordeel" (voordrag by die Studiegroep vir Letterkunde, Universiteit van Pretoria, ongepubliseerd), 22 April 1987, 5.

57. Iser, a w, 1978, 25.

58. Ibid, 24.

59. Lategan, a $w, 116$.

60. Holub, a w, 150.

61. R Selden, Criticism and objectivity, London: Allen \& Unwin, 1984, 107. 
62. Van Aarde, a w, 551.

63. Selden, a $w, 91$.

64. Vergelyk iser, a w, 1978, 22.

65. Ibid, 24.

66. Deist, a w, 1978, 264.

67. Vergelyk Deist, a $w, 1988,41,42$.

68. Vergelyk Mouton, a w, 1987, 11.

69. J Mouton \& H C Marais, "Metodologie in die geesteswetenskappe: basiese begrippe", RGN-studies in navorsingsmetodologie 1 (1985), 15.

70. Jauss, a $w, 18$.

71. Vergelyk byvoorbeeld iser, a $w, 1978, x i$.

72. Vergelyk Lategan, a $w, 116$.

73. Vergelyk P Nel, “Eksegese as 'n proses van hermitologisering: 'n kritiese bespreking van die benadering van Eugene Drewermann", NGTT vol 27 (1986), 17.

74. Vergelyk Van Aarde, a w, 548. 